\title{
Hydrogen peroxide interference in chemical oxygen demand during ozone based advanced oxidation of anaerobically digested livestock wastewater
}

\author{
${ }^{1}$ E. Lee; ${ }^{1}$ H. Lee; ${ }^{2}$ Y. K. Kim; ${ }^{3}$ K. Sohn; ${ }^{1 *}$ K. Lee \\ ${ }^{1}$ Departement of Environmental Engineering and Biotechnology, Myongji University, Yongin, 449-728, Korea \\ ${ }^{2}$ Departement of Environmental Engineering, Hankyong National University, Ansung, 456-749, Korea \\ ${ }^{3}$ HaeSung Engineering, Inc., Suwon, 442-834, Korea \\ Received 19 July 2010; $\quad$ revised 19 January 2011; accepted 21 February 2011; $\quad$ available online 1 March 2011
}

\begin{abstract}
It is known that hydrogen peroxide interferes with chemical oxygen demand analysis by consuming oxidation agents such as potassium dichromate, thus leading to overestimation of the chemical oxygen demand measurements. The objective of the study was to investigate the effects of hydrogen peroxide interference and to determine true chemical oxygen demand values on interpreting treatment performance during ozone-based advanced oxidation of livestock wastewater in which hydrogen peroxide concentration and chemical oxygen demand values are dynamically changing. According to the chemical oxygen demand monitoring data, chemical oxygen demand values were always higher than the initial chemical oxygen demand load when hydrogen peroxide was involved and the treatment performance with ozone alone or ozone/ultraviolet was better than with coupled hydrogen peroxide. The extent of overestimation was proportional to the remaining hydrogen peroxide concentration and the average overestimation ratio in livestock wastewater was in the range of $0.50 \sim 0.58 \mathrm{mg}$ per $1 \mathrm{mg}$ of hydrogen peroxide, depending upon the quality of the wastewater treated. True chemical oxygen demand values were estimated by correlating the extent of overestimation with the remaining hydrogen peroxide concentration during treatment. The extent of overestimation decreased to zero gradually as the amount of hydrogen peroxide also approached zero as oxidation proceeded. The corrected chemical oxygen demand values indicated underlying tendency of oxidation, which could not be seen in the original chemical oxygen demand monitoring data. Application of ozone/hydrogen peroxide was more efficient for reducing chemical oxygen demand than ozone alone, as was ozone/hydrogen peroxide/ultraviolet compared to ozone/ultraviolet. When coupled with ozone, ultraviolet irradiation was more efficient than hydrogen peroxide for decreasing chemical oxygen demand during treatment of livestock wastewater.
\end{abstract}

Keywords: Advanced oxidation; Chemical oxygen demand; Hydrogen peroxide; Livestock wastewater; Ozone

\section{INTRODUCTION}

Proper treatment of livestock wastewater is important due to its high strength loads of organic compounds, although the amount is relatively small compared to municipal wastewater and other industrial wastewaters (Juang et al., 2009). Some organic constituents of livestock wastewater are very persistent, often remaining even after a series of biological treatments (Adams et al., 2009). Chemical oxidation process using strong oxidation agents is a good option for removing non-biodegradable organic compounds from biologically-treated effluent (Oeller and Demel, 1997; Arslan and Balcioglu, 2001; Yasar et

\*Corresponding Author Email: kisay@mju.ac.kr

Tel.: +82313306 689; Fax: +82313366336 al., 2007; Tambosi et al., 2009). As a chemical oxidation agent, ozone $\left(\mathrm{O}_{3}\right)$ can effectively remove both color and odor from water and gas stream (Barker and Jones, 1988; Sauze et al., 1991; Tosik and Wiktorowski, 2001; Gharbani et al., 2008; Oneby et al., 2010) and it produces less byproducts compared to chlorine-based oxidation (Richardson et al., 1999; Kleiser and Frimmel, 2000; Rakness, 2005). However, ozone alone is less effective for general chemical oxygen demand (COD) removal because its degradation of carbon-carbon covalent bonds is not that high (Hoigne and Bader, 1983; Fronk, 1987; Barker and Jones, 1988; Langlais et al., 1991). Therefore, application of ozone is often coupled with hydrogen peroxide $\left(\mathrm{H}_{2} \mathrm{O}_{2}\right)$ or ultraviolet (UV) irradiation 
in order to utilize radical oxidation, which ultimately results in increased removal of non-biodegradable COD and color (Legrini et al., 1993; Oeller et al., 1997; Tosik and Wiktorowski, 2001; Gunten, 2003; Samarghandi et al., 2007). COD is a major indicator of the extent of organic compound removal. The most widely used method for COD analysis is the closed reflux, colorimetric method with potassium dichromate $\left(\mathrm{K}_{2} \mathrm{Cr}_{2} \mathrm{O}_{7}\right)$ as an oxidation agent, as well described in Standard Methods (APHA et al., 2005). In order to obtain consistent results from person to person, using different equipment and in various lab environments, many people use a pre-formulated commercial reagent mixture for rapid COD analysis.

It is known that some inorganic species including chlorides and nitrites interfere with COD analysis, which consumes potassium dichromate. Significant levels of inorganic species such as ferrous iron, sulfide, and manganese can also cause inaccuracies in the COD analysis. Confusion in interpreting the COD results due to AOHAinterference by certain components can be avoided through the addition of specific reagents (Baumann, 1974; Vaidya, et al., 1997; Domini et al., 2006; APHA et al., 2005). However, if no appropriate prevention measures can be taken, the obtained monitoring results should be corrected by determining the extent of interference.

Hydrogen peroxide is often used in advanced oxidation processes (AOP) alone or together with other agents such as ozone and UV. It is well known that $\mathrm{H}_{2} \mathrm{O}_{2}$ interferes with $\mathrm{COD}$ analysis by consuming oxidation agents such as $\mathrm{K}_{2} \mathrm{Cr}_{2} \mathrm{O}_{7}$, thus leading to overestimation of the COD measurements. Talinli and Anderson (1992), Kuo (1992) and Kang et al. (1999) studied the interference of $\mathrm{H}_{2} \mathrm{O}_{2}$ on standard COD analysis using synthetic wastewater and proposed correlations for estimating true COD values. Their results were helpful in understanding the cause and extent of $\mathrm{H}_{2} \mathrm{O}_{2}$ interference; however, their studies were performed on static clean water or synthetic wastewaters, not on real wastewater. No opinion was offered on how to determine true COD values during advanced oxidation in which the $\mathrm{H}_{2} \mathrm{O}_{2}$ concentration and COD values are dynamically changing. The objective of the study was to investigate the effects of $\mathrm{H}_{2} \mathrm{O}_{2}$ interference on COD analysis during ozonebased advanced oxidation. First, the extent and cause of $\mathrm{H}_{2} \mathrm{O}_{2}$ interference, specifically the extent of overestimation of COD values in livestock wastewater were considered. Secondly, the determination of correct COD values, especially during the oxidation treatment of real livestock wastewater in the presence of ozone, $\mathrm{H}_{2} \mathrm{O}_{2}$ and/or UV was intended. The COD removal performances were also compared based upon corrected COD values of four combinations of AOP $\left(\mathrm{O}_{3}\right.$ alone, $\mathrm{O}_{3} /$ $\mathrm{H}_{2} \mathrm{O}_{2}, \mathrm{O}_{3} / \mathrm{UV}$ and $\mathrm{O}_{3} / \mathrm{H}_{2} \mathrm{O}_{2} / \mathrm{UV}$ ) along with the effects of $\mathrm{H}_{2} \mathrm{O}_{2}$ interference.

\section{MATERIALS AND METHODS}

Livestock wastewater

A sample of fresh livestock wastewater was collected from anaerobic digestion effluent obtained from a local piggery farm in Ansung, Korea, followed by storage at $4{ }^{\circ} \mathrm{C}$ to minimize substrate decomposition. Solid-liquid separation for the livestock wastewater was conducted by centrifugation. The obtained supernatant was used in the oxidation experiments after proper dilution. The characteristics of the wastewater are summarized in Table 1.

\section{Advance oxidation experiments}

A closed, cylindrical acrylic reactor with a total volume of $1.2 \mathrm{~L}$ (height, $43 \mathrm{~cm}$; diameter, $6 \mathrm{~cm}$ ) was used in the ozone experiments. A water jacket was installed outside of the reactor in order to circulate water and keep the reactor at room temperature $\left(20^{\circ} \mathrm{C}\right)$. A porous diffuser placed at the bottom of the reactor transferred ozone gas into aqueous solution, and a $15 \mathrm{~W}$ mercury low-pressure ultraviolet lamp (LPUV) was placed vertically in the center of the reactor (Fig. 1) to keep irradiation distance within 4 $\mathrm{cm}$. The reactor was filled with one liter working volume of diluted livestock wastewater. Advanced oxidation was performed with ozone alone and three combinations of oxidation agents $\left(\mathrm{O}_{3} / \mathrm{H}_{2} \mathrm{O}_{2}, \mathrm{O}_{3} / \mathrm{UV}\right.$ and $\left.\mathrm{O}_{3} / \mathrm{H}_{2} \mathrm{O}_{2} / \mathrm{UV}\right)$. Ozone was generated from dried pure

Table 1: Characteristics of livestock wastewater

\begin{tabular}{lr}
\hline Parameters & \multicolumn{1}{c}{ Values } \\
\hline $\mathrm{pH}$ & $8.4-8.6$ \\
Alkalinity & $4,700-4,860 \mathrm{mg} / \mathrm{L}$ \\
SCOD $_{\mathrm{Cr}}$ & $7,500-8,200 \mathrm{mg} / \mathrm{L}$ \\
$\mathrm{TOC}$ & $2,500-3,600 \mathrm{mg} / \mathrm{L}$ \\
$\mathrm{TP}$ & $100-105 \mathrm{mg} / \mathrm{L}$ \\
$\mathrm{TN}$ & $4,650-5,250 \mathrm{mg} / \mathrm{L}$ \\
$\mathrm{NH}_{3}-\mathrm{N}$ & $1,690-1,810 \mathrm{mg} / \mathrm{L}$ \\
$\mathrm{SS}$ & $1,020-1,520 \mathrm{mg} / \mathrm{L}$ \\
Color $(400 \mathrm{~nm})$ & $0.38-0.39$ \\
\hline
\end{tabular}




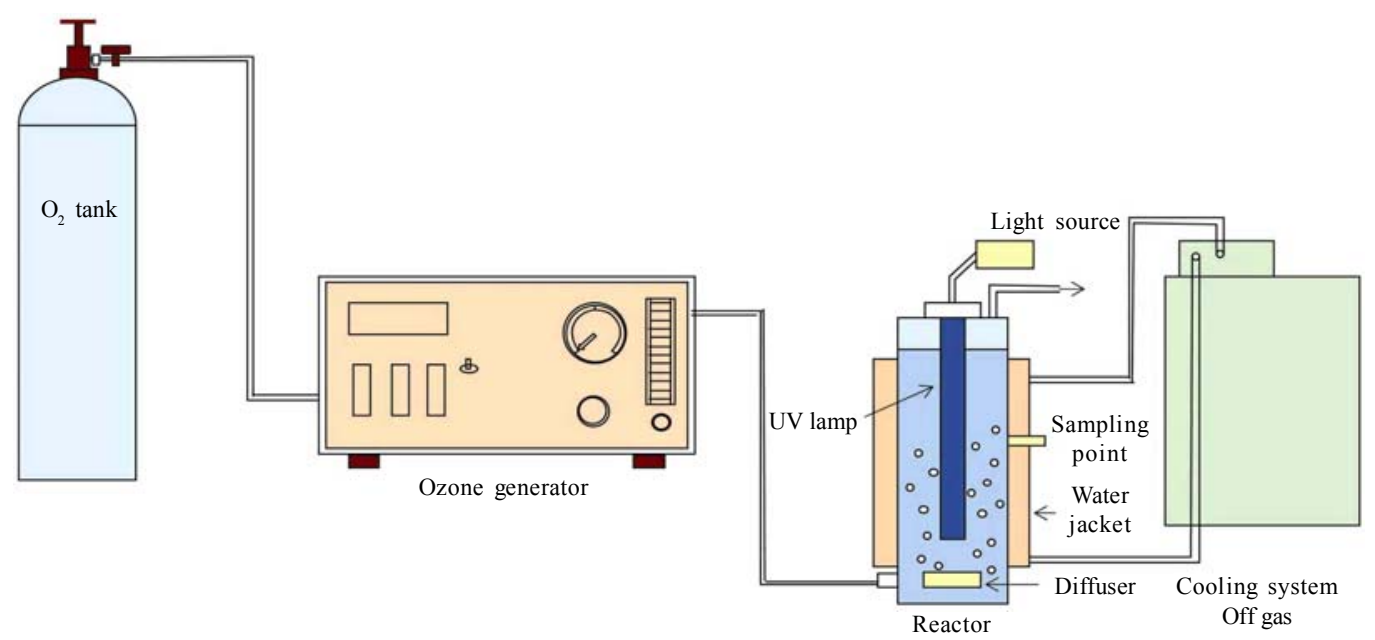

Fig. 1: Experimental system for ozone-based advanced oxidation

oxygen using an ozone generator (Ozonetech, Korea), which can produce a maximum of $11.2 \mathrm{~g} / \mathrm{h}$ of ozone. Ozone gas was fed to the oxidation reactor at the rate of $1.53 \mathrm{~g} / \mathrm{h}$. The administered dose of hydrogen peroxide $\left(\mathrm{H}_{2} \mathrm{O}_{2}\right.$, guaranteed reagent grade, Showa Chemical) was in the range of $0 \sim 200 \mathrm{mg} / \mathrm{L}$.

\section{Estimation of $\mathrm{H}_{2} \mathrm{O}_{2}$ interference on COD analysis}

To quantitate $\mathrm{H}_{2} \mathrm{O}_{2}$ interference during COD analysis, the extent of COD overestimation was determined along with its correlation with the $\mathrm{H}_{2} \mathrm{O}_{2}$ concentration. The livestock wastewater samples containing $100 \sim 800 \mathrm{mg} / \mathrm{L}$ ofCOD were prepared through serial dilution. Different concentrations of $\mathrm{H}_{2} \mathrm{O}_{2}$ were added to individual wastewater samples, each having a specific COD value. $\mathrm{COD}$ was measured immediately after the addition of $\mathrm{H}_{2} \mathrm{O}_{2}$ to the completely-mixed state, followed by comparison with the COD value with no $\mathrm{H}_{2} \mathrm{O}_{2}$.

To confirm that $\mathrm{H}_{2} \mathrm{O}_{2}$ has the same effect in other solutions, similar experiments were carried out using a solution of potassium hydrogen phthalate (KHP). KHP is often used as a standard analyte for COD analysis; $1 \mathrm{mg}$ of KHP has a theoretical COD value of $1.177 \mathrm{mg}$ (Vaidya et al., 1997; Domini et al., 2006). To make standard solutions for COD analysis, different amounts of KHP (Sigma-Aldrich) were dissolved in distilled water. Various concentrations of $\mathrm{H}_{2} \mathrm{O}_{2}$ were then added to the KHP solutions, after which COD was immediately determined. Based on the results of the above experiments, the extent of COD overestimation $(\triangle C O D)$ per unit of $\mathrm{H}_{2} \mathrm{O}_{2}$ could be determined. During oxidation of livestock wastewater, the true COD values were determined by analyzing the $\mathrm{H}_{2} \mathrm{O}_{2}$ concentration and by compensating for the measured $\triangle \mathrm{COD}$ values.

\section{Analytical methods}

The COD analysis was performed using a single lot of premixed digestion solution containing $\mathrm{K}_{2} \mathrm{Cr}_{2} \mathrm{O}_{7}$ as an oxidation agent along with other reagents $(\mathrm{HACH}$ COD Digestion Kit, Cat. No. 21259-15). The analysis was conducted according to the manufacturer's instructions with HACH DR4000 spectrophotometer $(\mathrm{HACH}, 2009)$. The quality of the raw livestock wastewater sample was analyzed according to the Standard Methods (APHA et al., 2005). For color value, the optical density at $400 \mathrm{~nm}$ was measured using a UV-Vis spectrophotometer by following the platinumcobalt standard method. The Indigo method was used in order to monitor the dissolved ozone concentration (Bader and Hoigne, 1981). $\mathrm{H}_{2} \mathrm{O}_{2}$ concentration was determined by the DMP (2, 9-dimethyl-1,10phenanthroline) method (Kosaka et al., 1998).

\section{RESULTS AND DISCUSSION}

Effects of $\mathrm{H}_{2} \mathrm{O}_{2}$ on livestock wastewater COD values

Fig. 2 shows changes in COD during the oxidation process of livestock wastewater containing $355 \mathrm{mg} / \mathrm{L}$ of initial COD using different combinations of oxidation methods. The combination of $\mathrm{O}_{3} / \mathrm{UV} / \mathrm{H}_{2} \mathrm{O}_{2}$ $(\Delta)$ resulted in the highest COD removal rate of $87 \%$ at $2 \mathrm{~h} \mathrm{O}_{3} / \mathrm{UV}$ (o) showed the next highest performance, followed by $\mathrm{O}_{3} / \mathrm{H}_{2} \mathrm{O}_{2}(\nabla)$ and $\mathrm{O}_{3}(\bullet)$ alone, which were similar. 
Some irregularities that were encountered when interpreting the measured COD values are presented in Fig. 2 Specifically, the COD data during the early stage of oxidation $(0 \sim 10 \mathrm{~min})$ by $\mathrm{O}_{3} / \mathrm{H}_{2} \mathrm{O}_{2}(\nabla)$ and $\mathrm{O}_{3} /$ $\mathrm{UV} / \mathrm{H}_{2} \mathrm{O}_{2}(\square)$ were about $24 \sim 26 \mathrm{mg} / \mathrm{L}$ higher than the initial COD load $(355 \mathrm{mg} / \mathrm{L})$ in untreated wastewater. This means that COD actually increased during the oxidation treatment instead of decreasing. Furthermore, the order of performances was different than expected; the performance of ozone alone $(\bullet)$ was higher than that of ozone $/ \mathrm{H}_{2} \mathrm{O}_{2}(\nabla)$ between $0 \sim 50$ min, whereas the performance of $\mathrm{O}_{3} / \mathrm{UV}(\mathrm{o})$ was higher than that of $\mathrm{O}_{3} / \mathrm{UV} / \mathrm{H}_{2} \mathrm{O}_{2}(\square)$. Generally, addition of $\mathrm{H}_{2} \mathrm{O}_{2}$ during ozone or UV treatment enhances the rate of COD degradation compared to treatment without $\mathrm{H}_{2} \mathrm{O}_{2}$, except when the radical scavenging effect of $\mathrm{H}_{2} \mathrm{O}_{2}$ is dominant (Gunten, 2003; Rosenfeldt et al., 2006; Tizaoui et al., 2007; Wu et al., 2007; Bandyopadhyay and Chattopadhyay, 2007; El Diwani et al., 2009). Therefore, these abnormal results could be due to interference by $\mathrm{H}_{2} \mathrm{O}_{2}$ since overestimation was not observed during treatment with ozone alone or $\mathrm{O}_{3} / \mathrm{UV}$.

Error in livestock wastewater $\mathrm{COD}$ values due to $\mathrm{H}_{2} \mathrm{O}_{2}$

To confirm the existence and extent of $\mathrm{H}_{2} \mathrm{O}_{2}$ interference on the COD values, COD analysis was performed using different concentrations of $\mathrm{H}_{2} \mathrm{O}_{2}$. Fig. 3 shows that the existence of $\mathrm{H}_{2} \mathrm{O}_{2}$ always led to COD overestimation and that the extent was proportional to the $\mathrm{H}_{2} \mathrm{O}_{2}$ concentration; for example, $56 \pm 5 \mathrm{mg} / \mathrm{L}$ ofCOD

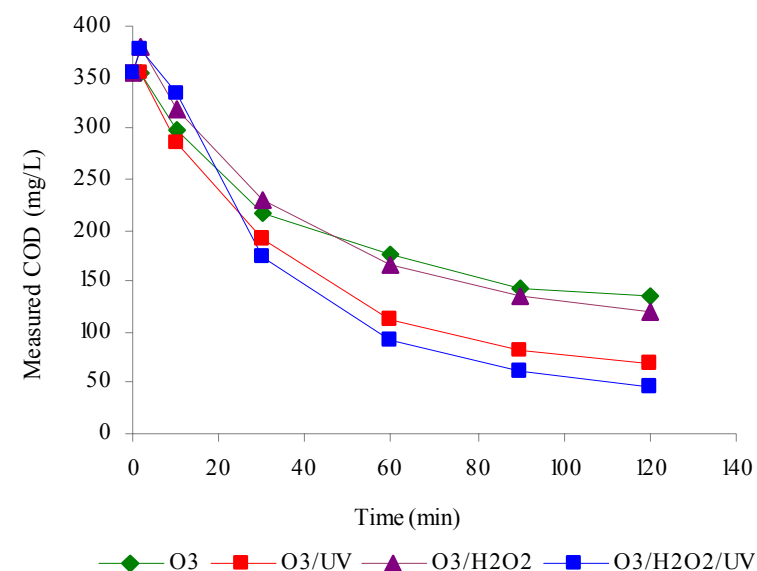

Fig. 2: Changes in COD measurements under different combinations of advanced oxidation for livestock wastewater treatment. The added $\mathrm{H}_{2} \mathrm{O}_{2}$ concentration was $50 \mathrm{mg} / \mathrm{L}$ for $100 \mathrm{mg} / \mathrm{L} \mathrm{H}_{2} \mathrm{O}_{2}$ and $26 \pm 3 \mathrm{mg} / \mathrm{L}$ of COD for $50 \mathrm{mg} / \mathrm{L}$ $\mathrm{H}_{2} \mathrm{O}_{2}$. The average overestimation ratio in livestock wastewater $\left(\triangle \mathrm{COD}_{\mathrm{Lww}}\right)$ was $0.52 \mathrm{mg}$ of COD per $\mathrm{mg}$ of $\mathrm{H}_{2} \mathrm{O}_{2}$ in the COD range of 0 to $400 \mathrm{mg} / \mathrm{L}$. It should be noted that the COD analysis was performed immediately after $\mathrm{H}_{2} \mathrm{O}_{2}$ addition in mixed wastewater samples. The $\mathrm{COD}$ values in the presence of $\mathrm{H}_{2} \mathrm{O}_{2}$ (vertical axis in Fig. 3) corresponding to zero COD value in the absence of $\mathrm{H}_{2} \mathrm{O}_{2}$ (horizontal axis on Fig. 3) represent COD values of standard $\mathrm{H}_{2} \mathrm{O}_{2}$ solutions.

Hydrogen peroxide is consumed during COD analysis by the following oxidation reaction with potassium dichromate (Talinli and Anderson, 1992):

$\mathrm{K}_{2} \mathrm{Cr}_{2} \mathrm{O}_{7}+3 \mathrm{H}_{2} \mathrm{O}_{2}+4 \mathrm{H}_{2} \mathrm{SO}_{4} \rightarrow \mathrm{K}_{2} \mathrm{SO}_{4}+\mathrm{Cr}_{2}\left(\mathrm{SO}_{4}\right)_{3}+7 \mathrm{H}_{2} \mathrm{O}+3 \mathrm{O}_{2}$

The theoretical COD value for $1 \mathrm{~g}$ of $\mathrm{H}_{2} \mathrm{O}_{2}$ based upon $\mathrm{Eq} \mathrm{(1)} \mathrm{is} 470.6 \mathrm{mg}$, which makes the COD overestimation ratio $0.47 \mathrm{mg} / \mathrm{L}$ of $\triangle C O D$ per $\mathrm{mg}$ of $\mathrm{H}_{2} \mathrm{O}_{2}$. The ratio (0.52) shown in Fig. 3 is a little higher than the theoretical one. The difference could be due to the premixed COD analysis kit. Several of the HACH mixtures used in this study consistently resulted in COD values that are 9 14\% higher than the theoretical COD values, which were calculated based upon the complete oxidation of potassium hydrogen phthalate (KHP), a standard analyte for COD analysis, in clean water samples. The extent of COD overestimation during the early stage of oxidation $(0 \sim 10 \mathrm{~min})$ by $\mathrm{O}_{3} /$ $\mathrm{H}_{2} \mathrm{O}_{2}(\nabla)$ and $\mathrm{O}_{3} / \mathrm{UV} / \mathrm{H}_{2} \mathrm{O}_{2}(\square)$ was approximately $24 \sim 26$ $\mathrm{mg} / \mathrm{L}$ (Fig. 2), which corresponds well to that in the

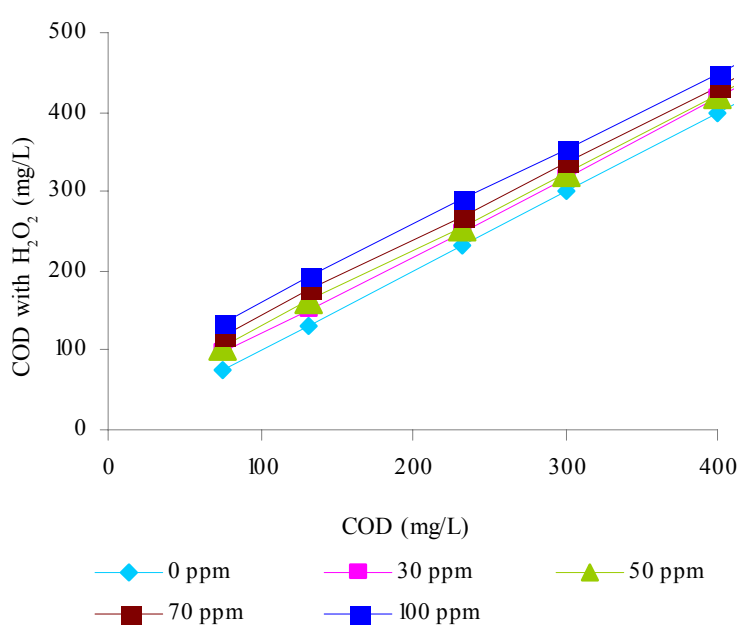

Fig. 3: Influence of $\mathrm{H}_{2} \mathrm{O}_{2}$ on $\mathrm{COD}$ values of livestock wastewater, the legend represents the added $\mathrm{H}_{2} \mathrm{O}_{2}$ concentrations 
presence of $50 \mathrm{mg} / \mathrm{L}$ of $\mathrm{H}_{2} \mathrm{O}_{2}$ (Fig. 3). These results imply that the data in Fig. 2 are not true COD values, specifically the values for $\mathrm{O}_{3} / \mathrm{H}_{2} \mathrm{O}_{2}$ and $\mathrm{O}_{3} / \mathrm{UV} / \mathrm{H}_{2} \mathrm{O}_{2}$. Therefore, some corrections are needed in order to estimate the true COD values when $\mathrm{H}_{2} \mathrm{O}_{2}$ is involved.

COD analysis using $\mathrm{K}_{2} \mathrm{Cr}_{2} \mathrm{O}_{7}$ was not influenced by ozone according to separate tests involving the addition of ozone to both wastewater and KHP solution, perhaps because the oxidation potential of $\mathrm{K}_{2} \mathrm{Cr}_{2} \mathrm{O}_{7}$ is smaller than that of ozone; $\mathrm{K}_{2} \mathrm{Cr}_{2} \mathrm{O}_{7}$ is not consumed in the oxidation of ozone.

Error in standard solution COD values due to $\mathrm{H}_{2} \mathrm{O}_{2}$

The extent of COD overestimation was proportional to the $\mathrm{H}_{2} \mathrm{O}_{2}$ concentration (Fig. 3). This was confirmed by measuring the COD value of the KHP solutions. KHP is often used as a standard COD analyte because it is completely oxidized by standard COD analysis; $1 \mathrm{mg}$ of KHP normally has a theoretical COD value of $1.177 \mathrm{mg}$. Fig. 4 shows the COD values obtained from different KHP concentrations in distilled water. $\mathrm{COD}_{\mathrm{KHP}}$ values linearly increase in proportion to the KHP concentration. Similar to Fig. 3, overestimation of COD was observed in the presence of $\mathrm{H}_{2} \mathrm{O}_{2}$, the extent of which was increased as the $\mathrm{H}_{2} \mathrm{O}_{2}$ concentration increased. For $\mathrm{COD}_{\mathrm{KHP}}$ values up to 1,000 $\mathrm{mg} / \mathrm{L}$ and $\mathrm{H}_{2} \mathrm{O}_{2}$ concentrations between $0 \sim 200 \mathrm{mg} / \mathrm{L}$, the average extent of COD overestimation in KHP solution $\left(\triangle \mathrm{COD}_{\mathrm{KHP}}\right)$ was approximately $0.58 \mathrm{mg}$ per $\mathrm{mg}$ of $\mathrm{H}_{2} \mathrm{O}_{2}$.

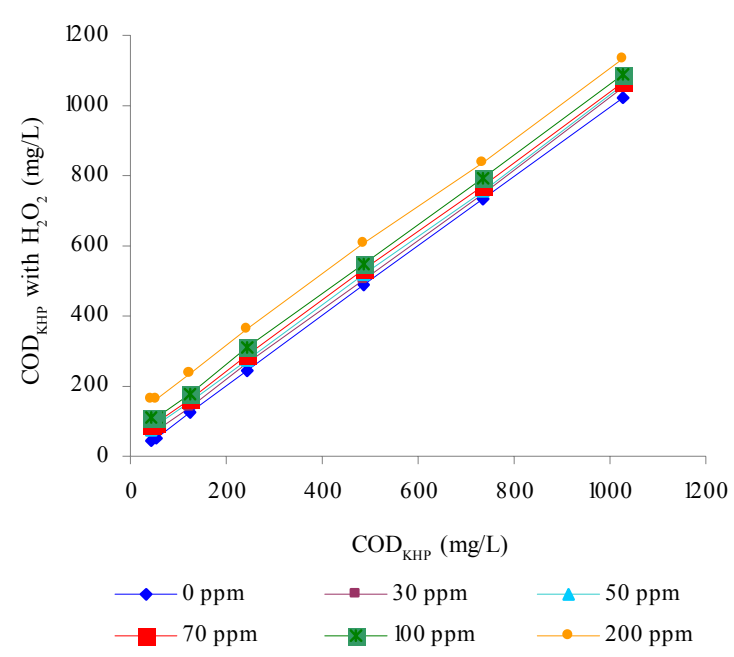

Fig. 4: Influence of $\mathrm{H}_{2} \mathrm{O}_{2}$ on COD values of KHP solution, the legend represents the added $\mathrm{H}_{2} \mathrm{O}_{2}$ concentrations
Comparison of Figs. 3 and 4 shows that the extent of COD overestimation per unit mass of $\mathrm{H}_{2} \mathrm{O}_{2}$ in KHP solution $\left(\triangle \mathrm{COD}_{\mathrm{KHP}}\right)$ was slightly greater than that in livestock wastewater $\left(\Delta \mathrm{COD}_{\mathrm{LWw}}\right)$. This suggests that real wastewater contains organic constituents that are more resistant to oxidation by $\mathrm{K}_{2} \mathrm{Cr}_{2} \mathrm{O}_{7}$ during COD analysis compared to clean water containing KHP only. Real livestock wastewater is not homogeneous in that it contains non-organic turbidity and color values that mitigate oxidation performance as well as organic compounds which are less vulnerable to oxidation by $\mathrm{K}_{2} \mathrm{Cr}_{2} \mathrm{O}_{7}$.
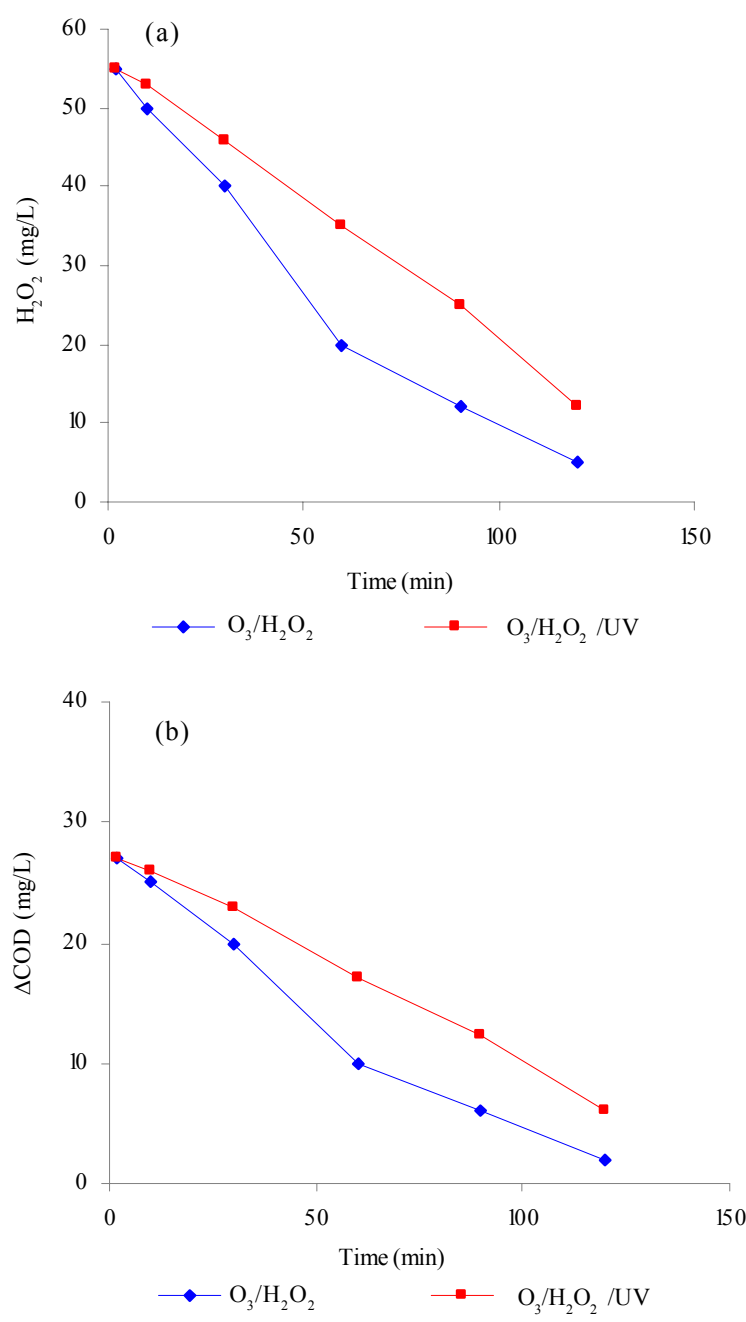

Fig. 5: Changes in (a) $\mathrm{H}_{2} \mathrm{O}_{2}$ concentration and (b) corresponding magnitude of COD overestimation $(\triangle \mathrm{COD})$ during oxidation 


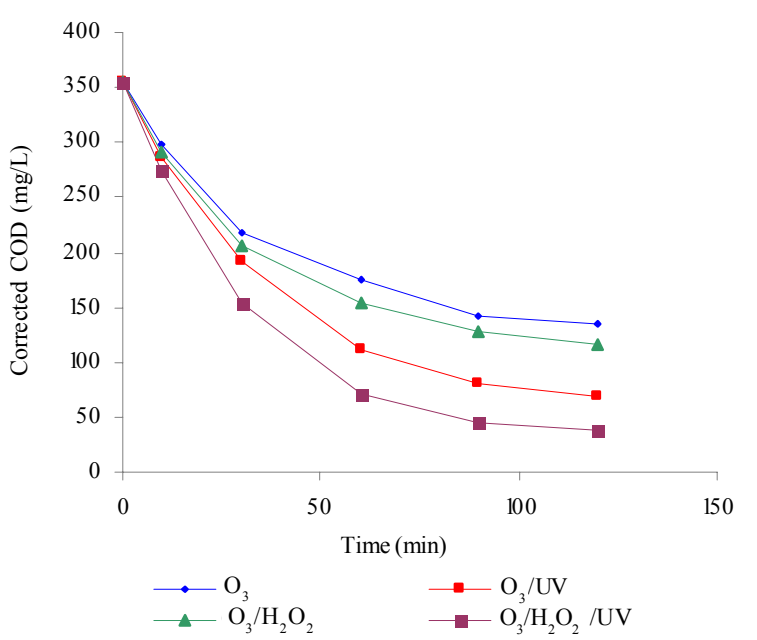

Fig. 6: Corrected COD values during advanced oxidation for livestock wastewater treatment

\section{Corrected COD values of livestock wastewater}

The results shown in Figs. 3 and 4, especially the linearity between $\triangle \mathrm{COD}$ and $\mathrm{H}_{2} \mathrm{O}_{2}$ content, imply that the extent of COD overestimation during oxidation can be determined relatively by correlating COD values with the $\mathrm{H}_{2} \mathrm{O}_{2}$ concentration, although the exact relationship is wastewater-dependent. Therefore, the true COD values were estimated by first determining the concentration of residual $\mathrm{H}_{2} \mathrm{O}_{2}$ in wastewater and then correlating it with $\triangle \mathrm{COD}$ during oxidation when the $\mathrm{H}_{2} \mathrm{O}_{2}$ concentration is continuously changing. During COD removal, some fraction of $\mathrm{H}_{2} \mathrm{O}_{2}$ must be converted into hydroxyl radicals especially when UV or ozone was applied with $\mathrm{H}_{2} \mathrm{O}_{2}$ Fronk, 1987; Gunten, 2003; Rosenfeldt et al., 2006; Kwon et al., 2009). Similar approach has been used to the treatment of industrial wastewaters using $\mathrm{H}_{2} \mathrm{O}_{2}$ alone (Zak, 2008).

Fig. 5 shows the change in residual $\mathrm{H}_{2} \mathrm{O}_{2}$ concentration during oxidation as well as any corresponding changes in $\triangle \mathrm{COD}$, which were estimated based upon the results of Fig. 3. The $\mathrm{H}_{2} \mathrm{O}_{2}$ concentration decreased from $50 \mathrm{mg} / \mathrm{L}$ to zero due to oxidation and/or conversion into hydroxyl radicals in the presence of ozone or UV. Consequently, $\triangle \mathrm{COD}$ decreased gradually from $27 \mathrm{mg} / \mathrm{L}$ to zero as the amount of $\mathrm{H}_{2} \mathrm{O}_{2}$ also approached zero.

Fig. 6 shows the true COD values obtained by subtracting $\triangle \mathrm{COD}$ (Fig. $5 \mathrm{~b}$ ) from the measured COD values (Fig. 2). If we compare the measured COD values (Fig. 2) to their corresponding correct ones (Fig. 6), overestimation between $0 \sim 10 \mathrm{~min}$ disappeared and all COD curves smoothly decreased, as was the case for $\mathrm{H}_{2} \mathrm{O}_{2}$ in Fig. 2. The COD removal performances for $2 \mathrm{~h}$ of treatment were $54 \%$ by $\mathrm{O}_{3}$ alone and then $62 \%, 78 \%$ and $88 \%$ by $\mathrm{O}_{3} / \mathrm{H}_{2} \mathrm{O}_{2}, \mathrm{O}_{3} /$ $\mathrm{UV}$ and $\mathrm{O}_{3} / \mathrm{H}_{2} \mathrm{O}_{2} / \mathrm{UV}$, respectively.

The true COD values in Fig. 6 reveal some important characteristics of COD removal among the different combinations of oxidation methods. First of all, $\mathrm{O}_{3} /$ $\mathrm{H}_{2} \mathrm{O}_{2}$ was more efficient in removing COD from livestock wastewater than $\mathrm{O}_{3}$ alone. This was also true for $\mathrm{O}_{3} / \mathrm{H}_{2} \mathrm{O}_{2} / \mathrm{UV}$ compared to $\mathrm{O}_{3} / \mathrm{UV}$. As seen in Figs. 6 and $2, \mathrm{O}_{3} / \mathrm{UV}$ consistently performed better than $\mathrm{O}_{3} / \mathrm{H}_{2} \mathrm{O}_{2}$ during oxidation, implying that $\mathrm{UV}$ irradiation coupled with $\mathrm{H}_{2} \mathrm{O}_{2}$ removed COD from livestock wastewater better than applying $\mathrm{O}_{3} / \mathrm{H}_{2} \mathrm{O}_{2}$ together.

\section{CONCLUSION}

This study investigated the effects of $\mathrm{H}_{2} \mathrm{O}_{2}$ interference during ozone-based advanced oxidation of livestock wastewater in which $\mathrm{H}_{2} \mathrm{O}_{2}$ concentration and COD values are dynamically changing and determined true COD values which were utilized in interpreting treatment performance.

The existence of $\mathrm{H}_{2} \mathrm{O}_{2}$ leads to overestimation of measured COD values since it consumes the oxidation agent. The extent of $\mathrm{H}_{2} \mathrm{O}_{2}$ interference in $\mathrm{COD}$ analysis was proportional to the remaining $\mathrm{H}_{2} \mathrm{O}_{2}$ concentration at the moment of sampling. The $\triangle \mathrm{COD}$ varied between $0.50 \sim 0.58 \mathrm{mg}$ per $1 \mathrm{mg}$ of $\mathrm{H}_{2} \mathrm{O}_{2}$, depending upon wastewater quality or the persistency of organic materials in the wastewater. To determine the true COD values during oxidation, the $\triangle \mathrm{COD}$ along with its correlation with the remaining $\mathrm{H}_{2} \mathrm{O}_{2}$ concentration were evaluated. True COD values were recalculated by considering the $\triangle C O D$ owing to remaining $\mathrm{H}_{2} \mathrm{O}_{2}$.

The resulting true COD values allowed reinterpretation of the oxidation process, which could not be seen in the measured COD data. The COD removal performances for $2 \mathrm{~h}$ of treatment, based upon corrected COD values, were $54 \%, 62 \%, 78 \%$ and 88 $\%$ by $\mathrm{O}_{3}, \mathrm{O}_{3} / \mathrm{H}_{2} \mathrm{O}_{2}, \mathrm{O}_{3} / \mathrm{UV}$ and $\mathrm{O}_{3} / \mathrm{H}_{2} \mathrm{O}_{2} / \mathrm{UV}$, respectively. Although specific to the livestock wastewater and treatment conditions in this study, $\mathrm{O}_{3} / \mathrm{H}_{2} \mathrm{O}_{2}$ was more efficient in removing COD than $\mathrm{O}_{3}$ alone while application of $\mathrm{O}_{3} / \mathrm{H}_{2} \mathrm{O}_{2} / \mathrm{UV}$ was superior to $\mathrm{O}_{3} / \mathrm{UV}$. Furthermore, when coupled with ozone, UV irradiation coupled with $\mathrm{O}_{3}$ degraded COD better than $\mathrm{O}_{3} / \mathrm{H}_{2} \mathrm{O}_{2}$ combination. 


\section{ACKNOWLEDGEMENTS}

This study was financially supported by 2008 Industry-Academia Joint Research Program of Small and Medium Business Administration (SMBA-2008-1EN-4), Korea, in cooperation with Hae-Sung Engineering, Inc. Eunyoung and Hyejung are also thankful to scholarship from BK21 Program of the Ministry of Education, Korea.

\section{REFERENCES}

Adams, R. H.; Ola¡n-Castro, D.; Guzmajn-Osorio, F. J.; DaazRamirez, I. J., (2009). Relationship between geomorphology and contamination with weathered hydrocarbons in an old river levee/ marsh association. Int. J. Environ. Sci. Tech., 6 (4), 527-538 (12 Pages),

APHA; AWWA; WEF, (2005). Standard methods for the examination of water and wastewater. $21^{\text {st }}$ Ed., American Public Health Association, American Water Works Association and the Water Environment Federation. Washington DC., USA.

Arslan, I.; Balcioglu, I., (2001). Advanced oxidation of raw and biotreated textile industry wastewater with $\mathrm{O}_{3}, \mathrm{H}_{2} \mathrm{O}_{2} / \mathrm{UV}$ $\mathrm{C}$ and their sequential application. J. Chem. Tech. Biotech., 76 (1), 53-60 (8 pages).

Bader, H.; Hoigne, J., (1981). Determination of ozone in water by the indigo method. Water Res., 15 (4), 449-456 (8 pages).

Bandyopadhyay, G.; Chattopadhyay, S., (2007). Single hidden layer artificial neural network models versus multiple linear regression model in forecasting the time series of total ozone. Int. J. Environ. Sci. Tech., 4 (1), 141-150 (10 Pages)

Barker, R.; Jones, A. R., (1988). Treatment of maloderants in air by UV/ozone technique. Ozone Sci. Eng., 10 (4), 405417 (13 pages).

Baumann, F. J., (1974). Dichromate reflux chemical oxygen demand: A proposed method for chloride in highly saline wastes. Anal. Chem., 46 (9), 1336-1338 (3 pages).

Domini, C. E.; Hidalgo, M.; Marken, F.; Canals, A., (2006). Comparison of three optimized digestion methods for rapid determination of chemical oxygen demand: Closed microwaves, open microwaves and ultrasound irradiation. Anal. Chim. Acta, 561 (1-2), 210-217 (8 pages).

El Diwani, G.; El Rafie; S.; Hawash, S., (2009). Degradation of 2, 4, 6-trinitotoluene in aqueous solution by ozonation and multi-stage ozonation biological treatment. Int. J. Environ. Sci. Tech., 6 (4), 619-628 (10 Pages).

Fronk, C. A., (1987). Destruction of volatile organic contaminants in drinking water by ozone treatment. Ozone Sci. Eng., 9 (3), 265-288 (24 pages).

Gharbani, P.; Tabatabaii, S. M.; Mehrizad, A., (2008). Removal of Congo Red from textile wastewater by ozonation. Int. J. Environ. Sci. Tech., 5 (4), 495-500 (6 pages).

Gunten, U., (2003). Ozonation of drinking water: Part I. Oxidation kinetics and product formation. Water Res., 37 (7), 1443-1467 (15 pages).

HACH, (2009). Oxygen Demand, Chemical Method 8000. DR/ 4000 Procedure.

Hoigne, J.; Bader, H., (1983). Rate constants of reactions of ozone with organic and inorganic compounds in water. Water
Res., 17 (2), 185-194 (10 pages).

Juang, D. F.; Lee, C. H.; Hsueh, S. C., (2009). Chlorinated volatile organic compounds found near the water surface of heavily polluted rivers. Int. J. Environ. Sci. Tech., 6 (4), 545-556 (12 Pages).

Kang, Y. W.; Cho, M. J.; Hwang, K. Y., (1999). Correction of hydrogen peroxide interference on standard chemical oxygen demand test. Water Res., 33 (5), 1247-1251 (5 pages).

Kleiser, G.; Frimmel, F. H., (2000). Removal of precursors for disinfection by-products: differences between ozone- and OH-radical-induced oxidation. Sci. Total Environ., 256 (1), 1-9 (9 pages).

Kosaka, K.; Yamada, H.; Matsui, S.; Echigo, S.; Shishida, K., (1998). Comparison among the methods for hydrogen peroxide measurements to evaluate advanced oxidation processes: Application of a spectrophotometric method using copper (II) ion and 2, 9-dimethyl-1, 10-phenanthroline. Environ. Sci. Tech., 32 (23), $3821-3824$ (4 pages).

Kuo, W. G., (1992). Decolorizing dye wastewater with Fenton's reagent. Water Res., 26 (7), 881-886 (6 pages).

Kwon, B. G.; Ryu, S.; Yoon, J., (2009). Determination of hydroxyl radical rate constans in a continuous flow system using competition kinetics. J. Ind. Eng. Chem., 15 (6), 809812 (4 pages).

Langlais, B.; Reckhow, D. A.; Brink, D. R., (1991). Ozone in water treatment: Application and engineering, Lewis Publishers.

Legrini, O.; Oliveros, E.; Braun, A. M., (1993). Photochemical processes for water treatment. Chem. Rev., 93 (2), 671698 (8 pages).

Oeller, H. J.; Demel, I.; Weinberger, G., (1997). Reduction in residual COD in biologically treated paper mill effluents by means of combined ozone and ozone/UV reactor stages. Water Sci. Tech., 35 (2-3), 269-276 (8 pages).

Oneby, M. A.; Bromley, C. O.; Borchardt, J. H.; Harrison, D. S., (2010). Ozone treatment of secondary effluent at U. S. municipal wastewater treatment plants. Ozone Sci. Eng., 32 (1), 43-55 (13 pages).

Rakness, K. L., (2005). Ozone in drinking water treatment: process design, operation, and optimization, AWWA.

Richardson, S. D.; Thruston, A. D.; Caughran, T. V.; Chen, P. H.; Collette, T. W.; Floyd, T. L., (1999). Identification of new ozone disinfection byproducts in drinking water. Environ. Sci. Tech., 33 (19), 3368-3377 (10 pages).

Rosenfeldt, E. J.; Linden, K. G.; Canonica, S.; von Gunten, V., (2006). Comparison of the efficiency of $\mathrm{OH}$ radical formation during ozonation and the advanced oxidation processes $\mathrm{O}_{3} / \mathrm{H}_{2} \mathrm{O}_{2}$ and $\mathrm{UV} / \mathrm{H}_{2} \mathrm{O}_{2}$. Water Res., 40 (20), 36953704 (10 pages).

Samarghandi, M. R.; Nouri, J.; Mesdaghinia, A. R.; Mahvi, A. H.; Nasseri, S.; Vaezi, F., (2007). Efficiency removal of phenol, lead and cadmium by means of UV/ TiO2/ H2O2 rocesses. Int. J. Environ. Sci. Tech., 4 (1), 19-26 (8 Pages).

Sauze, N.; Laplanche, A.; Martin, G.; Paillard, H., (1991). A process of washing and ozonation to deodorize an atmosphere contaminated by sulfides. Ozone Sci. Eng., 13 (3), 331-347 (18 pages).

Talinli, I.; Anderson, G. K., (1992). Interference of hydrogen peroxide on the standard COD test. Water Res., 26 (1), 107-110 (4 pages).

Tambosi, J. L.; de Sena, R. F.; Gebhardt, W.; Moreira, R.; Jose, 
H. J.; Schroder, H. F., (2009). Physicochemical and advanced oxidation process: A comparison of elimination results of antibiotic compounds following an MBR treatment. Ozone Sci. Eng., 31 (6), 428-435 (8 pages).

Tizaoui, C.; Bouselmi, L.; Mansouri, L.; Ghrabi, A., (2007). Landfill leachate treatment with ozone/hydrogen peroxide systems. J. Hazard. Mater., 140 (1-2), 316-324 (9 pages). Tosik, R.; Wiktorowski, S., (2001). Color removal and improvement of biodegradability of wastewater from dye production using ozone and hydrogen peroxide. Ozone Sci. Eng., 23 (4), 295-302 (8 pages).

Vaidya, B.; Watson, S. W.; Coldiron, S. J.; Porter, M. D., (1997). Reduction of chloride ion interference in chemical oxygen demand determination using bismuth-based adsorbents. Anal. Chim. Acta, 357 (1-2), 167-175 (8 pages).

Wu, J. J.; Muruganandham, M.; Chen, S. H., (2007). Degradation of DMSO by ozone-based advanced oxidation processes. J. Hazard. Mater., 149 (1), 218-225 (8 pages).

Yasar, A.; Ahmad, N.; Chaudry, M. N.; Rehman, M. S. U.; Khan, A. A., (2007). Ozone for color and COD removal of raw and anaerobic biotreated combined industrial wastewater. Pol. J. Environ. Stud., 16 (2), 289-294 (6 pages).

Zak, S., (2008). Problem of correction of the chemical oxygen demand values determined in wastewaters treated by methods with hydrogen peroxide. Proc. ECOpole, 2 (2), 409-414 (5 pages).

\section{AUTHOR (S) BIOSKETCHES}

Lee E., M.Sc, Researcher in the Laboratory Environmental Chemical Engineering, Department of Environmental Engineering and Biotechnology, Myongji University, Yongin, 449-728, Korea. Email: mysky7979@hanmail.net

Lee H., M.Sc., Graduate student in the Department of Environmental Engineering and Biotechnology, Myongji University, Yongin, 449728, Korea. Email: 0220lhj@hanmail.net

Kim Y.K, Ph.D., Professor in the Department of Environmental Engineering, Hankyong National University, Ansung, 456-749, Korea. Email: ykkim@hknu.ac.kr

Sohn K., M.Sc., Environmental Engineer, HaeSung Engineering, Inc., Suwon, 442-834, Korea. Email: kyryongs@hanmail.net

Lee K., Ph.D., Professor in the Department of Environmental Engineering and Biotechnology, Myongji University, Yongin, 449-728, Korea. Email: kisay@mju.ac.kr 